\title{
Sediment and nutrient loads into river Lwiro, in the Lake Kivu basin, Democratic Republic of Congo
}

\author{
M. BAGALWA ${ }^{1,2^{*}}$, J.G.M. MAJALIWA ${ }^{1}$, F. KANSIIME $^{1}$, S. BASHWIRA ${ }^{2,3}$, \\ M. TENYWA ${ }^{1}$ and K. KARUME ${ }^{4}$ \\ ${ }^{1}$ College of Agricultural and Environmental Sciences, Makerere University, \\ P.O. Box 7062, Kampala, Uganda. \\ ${ }^{2}$ Centre de Recherche en Science Naturelles de Lwiro, Bukavu, D. R. Congo, \\ C/O Petit Séminaire de Mugéri, BP 02, Bukavu, via Cyangugu, D. R. Congo. \\ ${ }^{3}$ Université Catholique de Bukavu, D. R. Congo. \\ ${ }^{4}$ Observatoire Volcanologique de Goma, D. R. Congo. \\ *Corresponding author, E-mail: mashibagalwa@yahoo.fr
}

\begin{abstract}
This study assessed sediment and nutrient loads in Lwiro river, Lake Kivu basin in the Democratic Republic of Congo. Water discharge was measured and water samples were collected twice a month from 6 sites in Lwiro river system and analyzed for total suspended sediment (SS), temperature, $\mathrm{pH}$, dissolved oxygen (DO), chemical oxygen demand (COD), five-day biological oxygen demand $\left(\mathrm{BOD}_{5}\right)$, alkalinity and nutrients $\left(\mathrm{P}, \mathrm{N}, \mathrm{PO}_{4}{ }^{3-}, \mathrm{NO}_{3}{ }^{-}\right.$and $\mathrm{NH}_{4}{ }^{+}$) using standard methods. Results show that the concentration of $\mathrm{BOD}_{5}$ was low $(1.08 \pm 0.83 \mathrm{mg} / \mathrm{L})$; but COD $(13.13 \pm 6.26 \mathrm{mg} / \mathrm{L})$ and $\mathrm{SS}(1.15 \pm 0.36 \mathrm{mg} / \mathrm{L})$ were high in the industrial effluent than in agricultural effluent $\left(2.7 \pm 0.77 \mathrm{mg} / \mathrm{L}\right.$ for $\mathrm{BOD}_{5} ; 9.05 \pm 3.55 \mathrm{mg} / \mathrm{L}$ for COD and $0.81 \pm 0.36$ $\mathrm{mg} / \mathrm{L}$ for TSS). It was observed that all these values were low compared to the standard limit proposed by UNECE and Uganda standard. TSS, nutrient and other chemicals parameters load analyzed were high in agriculture effluent than in industrial effluent except for $\mathrm{NH}_{4}{ }^{+}$load. Temporal variation and site difference between TSS and nutrient load were significantly different $(\mathrm{F}=5.54, \mathrm{p}<0.005$ for $\mathrm{SS} ; \mathrm{F}=8.59, \mathrm{p}<0.005$ for TP and $\mathrm{F}=7.63, \mathrm{p}<0.005$ for TN). Techniques for reducing nutrient and TSS loads should be initiated in the microcatchment to protect the Lake Kivu.
\end{abstract}

(C) 2015 International Formulae Group. All rights reserved.

Keywords: Sediment; nutrient load; industrial; agriculture effluent; Lwiro river; Lake Kivu.

\section{INTRODUCTION}

Rivers play an important role in a watershed for carrying off municipal and industrial wastewater and run-off from farm land, and are one of the most susceptible water bodies to pollutants (Wang et al., 2007; Fan et al., 2010). The constant discharges of domestic and industrial wastewater and seasonal surface run-off have a strong effect on the river discharge and water quality (Wang et al., 2007; Loko et al., 2013). Therefore, it is imperative and important to have reliable information on characteristics of water quality for effective pollution control and water resource management. There is a great need to evaluate the river water quality. 
Surface waters are controlled by both the natural processes, i.e. precipitation inputs, erosion, weathering, and the anthropogenic activities via point sources, such as industrial effluents and wastewater treatment facilities, and diffuse such as runoffs from urban area and farming land ( $\mathrm{Li}$ and Zhang, 2008; Li et al., 2009; Banadda et al., 2009). Studies demonstrate that surface water quality has deteriorated noticeably in many countries in the past decades due to poor land use practices (Liu et al., 2003; Banadda et al., 2009), indicating by the strong relationships between declining water quality and increasing agricultural development at catchment scale (Buck et al., 2004; Banadda et al., 2009). Therefore, researchers have been paying more attention to the effect of land use on water quality, in particular the key contributors of agricultural activities to nutrients and suspended particulate matter (Buck et al., 2004; Banadda et al., 2009).

In the last few decades, Lake Kivu has undergone major changes in chemistry and biology as a result of growing human interference and pollution from domestic, industrial and agricultural activities which lead to a deterioration of water quality (Muvundja et al., 2009; Schmid et al., 2010). Lake Kivu basin is used as a source of food, energy, drinking and irrigation water for shelter of endemic biodiversity and transport and as repository for human, agricultural and industrial waste. Development activities, discharge of nutrients, sediment and growth of population around the lake shore has caused changes in the Lake ecosystem. Sediment and nutrient loading into Lake Kivu is mainly linked to the rapid growth of population which has caused severe deforestation and severe soil erosion within the Lake basin (Bagalwa 2006). The increasing sediment, nutrients and others physico-chemical parameters pose also severe threats to biodiversity, the stability of the Lake basin and to soil fertility in declining crop yield (Hecky et al., 2003). The source of pollution loading into Lake Kivu, in Lwiro micro-catchment is not yet identified. In this micro-catchment, agriculture is the main activity of the population. It is done in inappropriate places.

Few studies (Bagalwa, 2006; Muvundja et al., 2009) were done in the river Lwiro. But they didn't identify the source of degradation of the quality of water in the river. It was hypothesized that agricultural activity, industrial waste and runoff in the microcatchment are a major source of sediment and nutrient loading in Lwiro river. This study was conducted to determine the sediment and nutrient loads into river Lwiro with a view to provide decision makers with a tool to evaluate management practices that would potentially reduce source pollution coming from the agricultural micro-catchment.

\section{MATERIALS AND METHODS}

\section{Sites description}

The Lwiro micro-catchment is located on the eastern flank of Lake Kivu, between latitude $2^{\circ} 15^{\prime}$ and $2^{\circ} 30^{\prime} \mathrm{S}$ and longitudes $28^{\circ} 45^{\prime}$ and $28^{\circ} 85^{\prime}$ E. Its headwaters are the Kahuzi-Biega National Park mountain region, at an altitude of $2000 \mathrm{~m}$. The $84 \mathrm{~km}^{2}$ river basin is bordered on the east by Lake Kivu and on the west by the Kahuzi mountain forest (Figure 1). This micro-catchment of Lwiro river, the principal tributary of the Lake Kivu, covers 4 localities namely Irhambi/Katana, Bugorhe, Luhihi and Bushumba in the territory of Kabare, province of South-Kivu, Democratic Republic of Congo. Rainfall is about $1500 \mathrm{~mm}$ annually (Bagalwa , 2006). The soil comprises clay and rich volcanic soil which is easily eroded. The geological composition is of Precambrian metamorphoses sediments (metamorphic rocks) and Preterozoic platform sediments (Moeyersons et al., 2004). Hills surrounding the lake are composed of an old geomorphologic structure which is currently undergoing a serious change due to soil 
erosion, landslides and seismicity (Mavonga, 2007, d'Oreye et al., 2011). Carbonates for the production of cement are also found north and north-west of Lake Kivu.

\section{Sampling sites locations}

The Lwiro river is approximately 27.2 $\mathrm{Km}$ long and has a mean width of $7 \mathrm{~m}$ (Bagalwa, 2006). A total of four stations (Figure 1) were selected on the basis of their accessibility throughout the year in the main river (Sites 1, 3, 5 and 6) and two stations (Sites 2 and 4) in the tributaries of the river.

Site 1 (Kayandja) was at $1680 \mathrm{~m}$ above mean sea level (amsl), near the BukavuGoma road, approximately $14.8 \mathrm{~km}$ downstream from the spring and between an irrigated sugarcane field and a coffee plantation in the main river. People use the site for bathing, and animal drinking and washing. The substratum is composed of mud and small stones. The vegetation consists of a mixture of emergent macrophytes, Commelina diffusa, Pennisetum purpureum and Riparia sp.

Site 2 (Myanzi-Lwiro) was at $1700 \mathrm{~m}$ amsl. The stream is a tributary of river Lwiro and passed in irrigated sector and agricultural. The substratum is composed principally of mud. The fields are composed by varieties of plants including vegetables, tomatoes, beans, maize, etc. At the upstream, constructed ponds are made for producing fishes for the population in the surroundings. The vegetation at the edge of the stream is usually removed during the time of cultivation.

Site 3 (Buhandahanda) was located $200 \mathrm{~m}$ at outlet of the Kalengo stream at 1644 $\mathrm{m}$ amsl in the main river. The border of the river is covered by Pennisetum purpureum.

Site 4 (outlet of coffee industry) was located at $1640 \mathrm{~m}$ amsl, and the outlet of the coffee industry and washing of mineral such of Colombo-tantalite and cassiterite. The channel is covered by banana plantation and pours into Lwiro river without treatment.
Site 5 (Kakondo) was located at 1640 $\mathrm{m}$ amsl and $26 \mathrm{~km}$ downstream. It is also located near a coffee-processing factory that discharges waste water into the river. The substratum is composed of mud and stones. Natural forest constituted by trees covered this site and made a shade.

Site 6 (Fomulac), was located $500 \mathrm{~m}$ upstream of the river at an elevation of 1460 $\mathrm{m}$ amsl. The site is dominated by sugarcane, while the river shore-line is covered by Cynondon dactylon and Pennisetum purpureum. The river passes through irrigated sugarcane fields.

\section{Sampling design}

The six sites were each sampled from July 2012-June 2013 in order to cover the rainy season (September-May) and the dry season (June-August). Total suspended sediment (TSS) and water discharge were collected daily at the outlet of the Lwiro river were a gauge was installed. Surface water temperature, Dissolved oxygen (DO), five-day biological oxygen demand $\left(\mathrm{BOD}_{5}\right)$, alkalinity and SS were measured twice a month in the different sites and analyzed following the procedures described in Golterman et al. (1978) and APHA (1989). On each occasion, samples were collected at $9.00 \mathrm{am}$, at a depth of $5 \mathrm{~cm}$ near midstream. The temperature was measured using an oxymeter. At each site, two water samples were collected in pre-washed glass bottles, for the measurement of DO and $\mathrm{BOD}_{5}$. After fixation in the field, DO was determined, following the iodometric Winkler's method (Golterman et al., 1978). $\mathrm{BOD}_{5}$ was measured as the decrease in DO after incubation in the dark at $20{ }^{\circ} \mathrm{C}$ for five days. Other water samples were taken in 11 bottles at the same time for other chemical analyses. Total alkalinity $\left(\mathrm{mgl}^{-1}\right)$ was determined by titration with $0.1 \mathrm{~N} \mathrm{HCl}$. TSS $\left(\mathrm{mgl}^{-1}\right)$, the latter were estimated by filtration of 11 of water through analytical filter paper 
(Whatman 589, $185 \mu \mathrm{m}$ pore size) and dried at $105^{\circ} \mathrm{C}$.

Annual loads was calculated for TSS, BOD, COD, TP, SRP, TN, Ammonium and Nitrate using mean water discharges, and concentrations at each site.

\section{Statistical analysis}

A one and two-way analysis of variance (ANOVA) was carried out to test for temporal and site differences. The paired t-test was used to evaluate seasonal differences. Pearson's correlation was calculated to establish the relationship between the parameters and some hydrological variables.

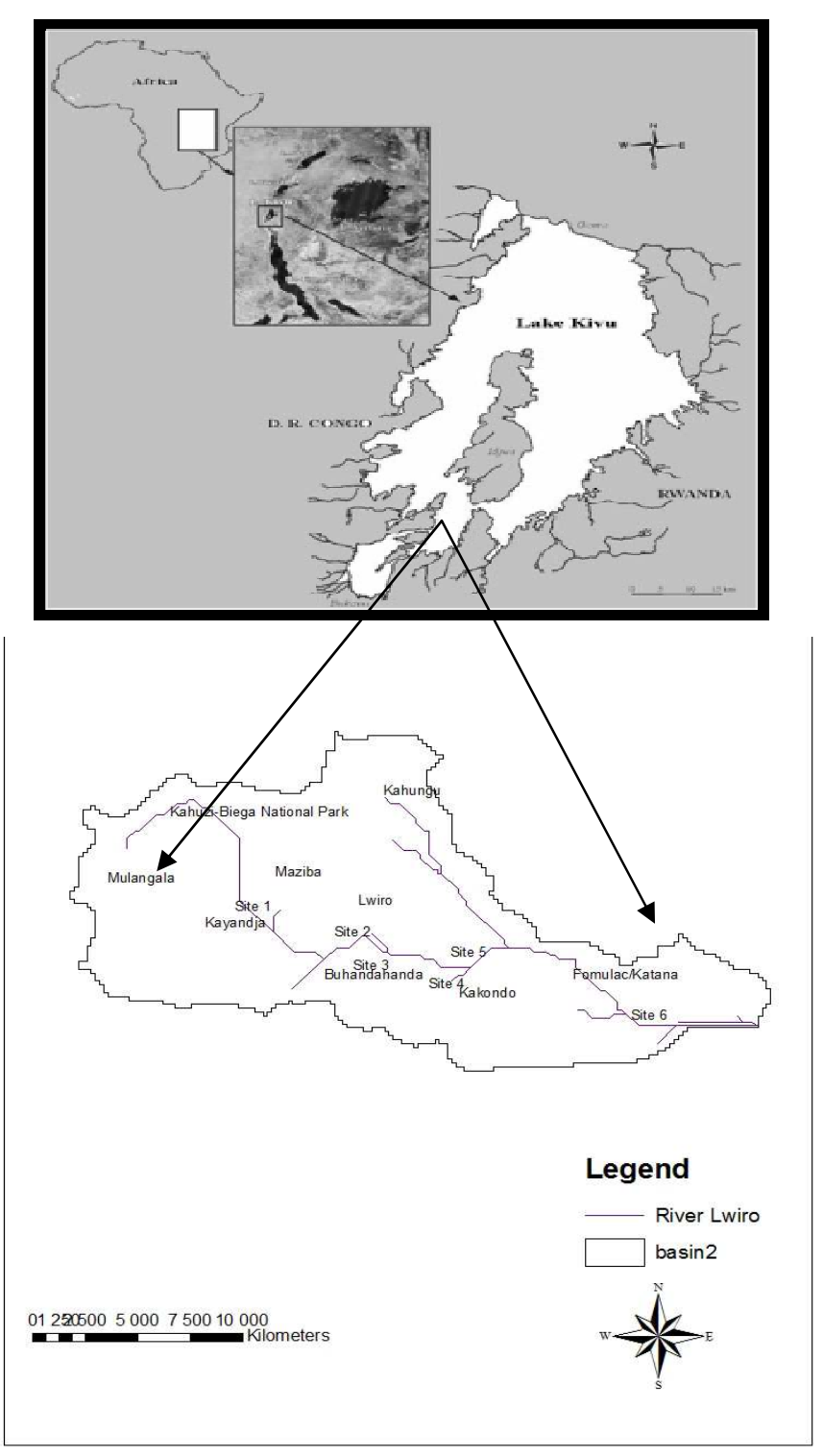

Figure 1: River Lwiro sub-catchment, Lake Kivu. 


\section{RESULTS}

Physico-chemical parameters of water in river Lwiro

The monthly variation of $\mathrm{BOD}_{5}, \mathrm{COD}$ and water discharge at the outlet is presented in Figure 2. $\mathrm{BOD}_{5}$ concentrations did not significantly vary from one month to another $(\mathrm{P}>0.05)$. Water discharge presented a peak in May while COD showed three peaks in April, July and September 2013.

Similarly, TP did not vary significantly with months; but TN followed the same trend like water discharge (Figure 3). TSS presented a peak in August, January and April 2013.

The monthly variation of TP, TN and TSS is present in Figure 4.

It was observed that TP was high in September, April and May 2013 during the rainy season and TN showed a pick in July and December 2013. TSS was high in January and April during also the rainy season.

The mean value of selected physicochemical parameters of waters in river are within the range proposed by UNECE (1994) and Uganda standard (Moses, 2005) for aquatic life, and showed a variation between the sites during the year. Effluent dominated by industrial and agricultural activities had relatively high values in terms of TP, SRP, $\mathrm{TN}, \mathrm{NH}_{4}{ }^{+}$and $\mathrm{NO}_{3}{ }^{-}$. Most of the parameters were relatively low at the outlet. Pearson's correlation of between the physico-chemical parameters the three sample sites are presented in Table 2 .

Some parameters are very strong correlated $(r>0.91)$ such as SS and COD with nutrient $(\mathrm{P}$ and $\mathrm{N}$ ) but the other parameters in general were strong and weak negative correlated $(\mathrm{r}<0.31)$. TSS is strong positively correlated with COD, TP, SRP, TN, $\mathrm{NH}_{4}^{+}$, $\mathrm{NO}_{3}{ }^{-}$and strong negatively correlated with $\mathrm{BOD}_{5}, \mathrm{pH}$ and $\mathrm{DO}$. The correlation of $\mathrm{BOD}_{5}$ is contrary to the correlation of TSS. It is strong negatively correlated with COD, TP, SRP, TN, $\mathrm{NH}_{4}{ }^{+}, \quad \mathrm{NO}_{3}{ }^{-}$and positively correlated with $\mathrm{pH}$ and DO. COD is correlated in the same way as TSS. Discharge is negatively correlated with the entire nutrient but positive correlation is recorded with $\mathrm{pH}$ and DO. TP, SRP, TN, $\mathrm{NH}_{4}{ }^{+}, \mathrm{NO}_{3}{ }^{-}$are strong positively correlated between them but negatively correlated with other parameters. Alkalinity is weakly correlated with all the other parameters investigated in this study.

Total Suspended Sediment, nutrient and others pollutants loading in the Lwiro river micro-catchment

The annual load of selected parameters in the Lwiro micro-catchment is presented in the Table 3.

The Total Suspended Sediment, nutrient and others pollutants loading in the different sites are different from one site to an others. The agricultural effluent has high loading of selected water quality parameters than the industrial effluent. Results show that biological oxygen demand $\left(\mathrm{BOD}_{5}\right)$, chemical oxygen demand (COD) and Total Suspended Sediment load are the lowest on the industrial effluent that in domestic and agricultural effluent. Total Phosphorus load is approximately the same in industrial and agriculture effluents but the variation seem to differentiate them. The same observation is also valuable for Soluble Reactive Phosphorus. Total Nitrogen is higher in agricultural than in industrial effluent. The same observation is made for Nitrate. But for Ammonium, the high load was observed in industrial effluent. The Total Suspended Sediment, nutrient and other pollutants load are high at the outlet compared to the input from agriculture and industrial load. 


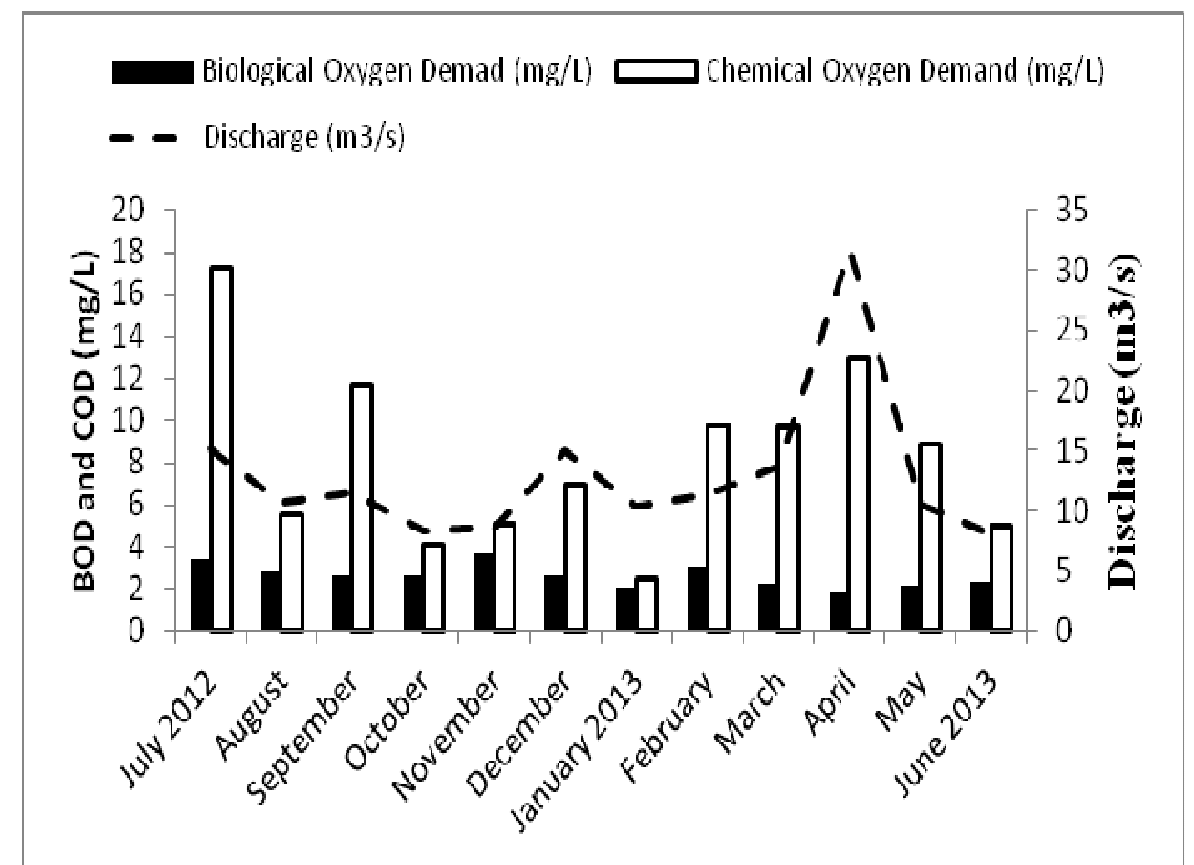

Figure 2: Monthly variation of discharge and $\mathrm{BOD}_{5}, \mathrm{COD}$ at the outlet of Lwiro river in the microcatchment.

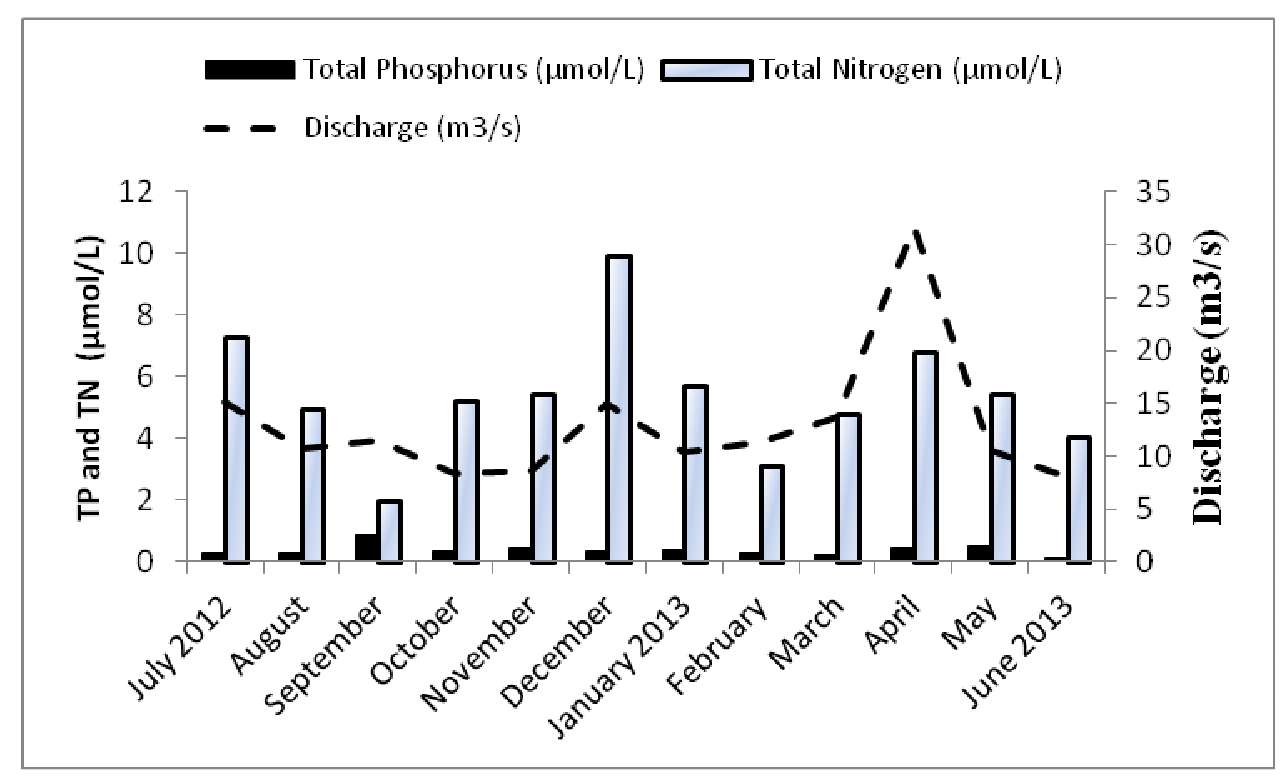

Figure 3: Monthly variation of discharge, TP and TN in the Lwiro micro-catchment. 


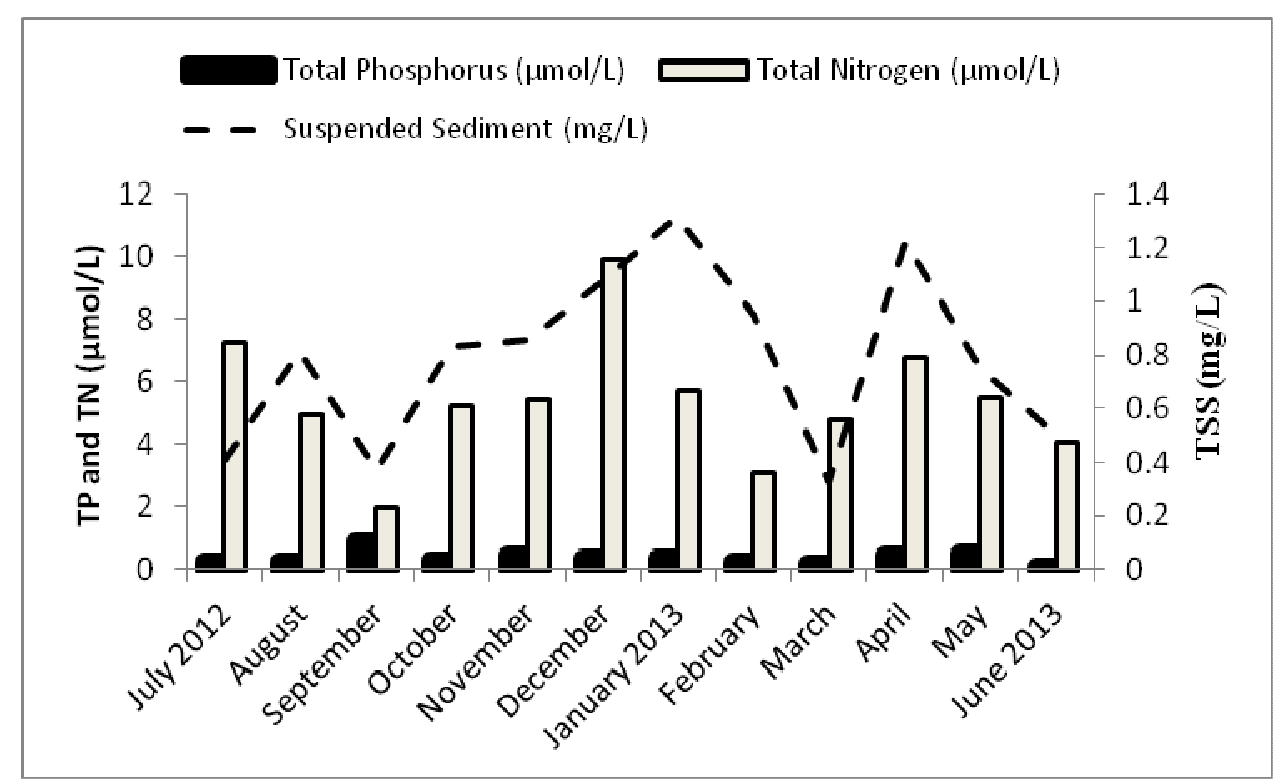

Figure 4: Monthly variation of TSS, TP and TN in the Lwiro micro-catchment.

Table 1: Mean physicochemical parameters of micro catchment (Mean $\pm \mathrm{SE})$.

\begin{tabular}{lcccc}
\hline Parameter & Agricultural & $\begin{array}{c}\text { Industrial } \\
\text { +Agric. }\end{array}$ & $\begin{array}{c}\text { Outlet } \\
\text { Uganda and } \\
\text { UNECE }\end{array}$ \\
\hline Temperature $\left({ }^{\circ} \mathrm{C}\right)$ & $20.14 \pm 0.86$ & $19.02 \pm 1.09$ & $18.46 \pm 1.03$ & $<37$ \\
$\mathrm{pH}$ & $7.91 \pm 0.41$ & $6.94 \pm 0.57$ & $7.95 \pm 0.43$ & 6.5 to 8.5 \\
Dissolved Oxygen $(\mathrm{mg} / \mathrm{L})$ & $4.94 \pm 0.97$ & $2.68 \pm 1.64$ & $5.40 \pm 0.55$ & 6 \\
Alkalinity $(\mathrm{mg} / \mathrm{L})$ & $33.08 \pm 11.01$ & $21.33 \pm 9.25$ & $17.79 \pm 5.44$ & 250 \\
Total Suspended Sediment $(\mathrm{mg} / \mathrm{L})$ & $0.81 \pm 0.36$ & $1.15 \pm 0.36$ & $0.78 \pm 0.32$ & 20 \\
Biological Oxygen Demand $(\mathrm{mg} / \mathrm{L})$ & $2.7 \pm 0.77$ & $1.08 \pm 0.83$ & $2.61 \pm 0.57$ & 50 \\
Chemical Oxygen Demand $(\mathrm{mg} / \mathrm{L})$ & $9.05 \pm 2.55$ & $13.13 \pm 6.26$ & $8.27 \pm 3.77$ & $10-20$ \\
Total Phosphorus $(\mu \mathrm{mol} / \mathrm{L})$ & $0.33 \pm 0.12$ & $1.89 \pm 1.76$ & $0.38 \pm 0.16$ & $0.6-1.28$ \\
Soluble Reactive Phosphorus $(\mu \mathrm{mol} / \mathrm{L})$ & $0.27 \pm 0.16$ & $1.32 \pm 1.32$ & $0.23 \pm 0.16$ & $\mathrm{NA}$ \\
Total Nitrogen $(\mu \mathrm{mol} / \mathrm{L})$ & $7.75 \pm 4.29$ & $33.95 \pm 31.27$ & $5.40 \pm 1.63$ & $50-100$ \\
Ammonia $(\mu \mathrm{mol} / \mathrm{L})$ & $0.98 \pm 0.75$ & $7.32 \pm 9.30$ & $0.54 \pm 0.26$ & 100 \\
Nitrate $(\mu \mathrm{mol} / \mathrm{L})$ & $2.81 \pm 1.62$ & $8.54 \pm 8.36$ & $1.88 \pm 1.20$ & $<45$ \\
Discharge $(\mathrm{m} 3 / \mathrm{S})$ & $0.67 \pm 0.38$ & $0.12 \pm 0.11$ & $12.89 \pm 3.98$ & $\mathrm{NA}$ \\
\hline
\end{tabular}

${ }^{1}$ Source: ECE (Economic Commission for Europe) standard limit values of surface freshwater quality for the maintenance of aquatic life (UNECE, 1994); NE: Not available. 
Table 2: Correlation coefficient $r$ for different physiochemical parameter for the outlet of river Lwiro ( $\mathrm{n}=24 / \mathrm{site})$.

\begin{tabular}{|c|c|c|c|c|c|c|c|c|c|c|c|c|c|}
\hline & TSS & $\mathrm{BOD}_{5}$ & COD & Disch & TP & SRP & TN & $\mathrm{NH}_{4}{ }^{+}$ & $\mathrm{NO}_{3}{ }^{-}$ & Temp & pH & DO & Alkal \\
\hline TSS & 0 & & & & & & & & & & & & \\
\hline $\mathrm{BOD}_{5}$ & -0.99 & 0 & & & & & & & & & & & \\
\hline COD & 1.00 & -0.98 & 0 & & & & & & & & & & \\
\hline Disch & -0.59 & 0.47 & -0.65 & 0 & & & & & & & & & \\
\hline TP & 1.00 & -1.00 & 0.99 & -0.51 & 0 & & & & & & & & \\
\hline SRP & 1.00 & -0.99 & 0.99 & -0.56 & 1.00 & 0 & & & & & & & \\
\hline TN & 1.00 & -0.99 & 1.00 & -0.59 & 0.99 & 1.00 & 0 & & & & & & \\
\hline $\mathrm{NH}_{4}^{+}$ & 1.00 & -0.99 & 1.00 & -0.58 & 1.00 & 1.00 & 1.00 & 0 & & & & & \\
\hline $\mathrm{NO}_{3}^{-}$ & 1.00 & -0.98 & 1.00 & -0.64 & 0.99 & 1.00 & 1.00 & 1.00 & 0 & & & & \\
\hline Temp & -0.13 & 0.27 & -0.05 & -0.73 & -0.22 & -0.16 & -0.12 & -0.13 & -0.06 & 0 & & & \\
\hline $\mathrm{pH}$ & -1.00 & 1.00 & -0.99 & 0.53 & -1.00 & -1.00 & -1.00 & -1.00 & -0.99 & 0.19 & 0 & & \\
\hline DO & -1.00 & 0.97 & -1.00 & 0.66 & -0.98 & -0.99 & -1.00 & -0.99 & -1.00 & 0.03 & 0.99 & 0 & \\
\hline Alkal & -0.23 & 0.37 & -0.16 & -0.65 & -0.32 & -0.27 & -0.22 & -0.24 & -0.17 & 0.99 & 0.30 & 0.14 & 0 \\
\hline
\end{tabular}

Table 3: Annual load of selected water quality parameters in river Lwiro (Mean \pm SE).

\begin{tabular}{lcccc}
\hline & Site 1 & Agriculture & Indus+Agriculture & Outlet \\
\hline Total Suspended Sediment (t/yr) & $66.92 \pm 10.69$ & $17.42 \pm 4.40$ & $4.60 \pm 1.32$ & $319.22 \pm 40.79$ \\
Biological Oxygen Demand (t/yr) & $303.98 \pm 27.68$ & $59.16 \pm 9.41$ & $4.31 \pm 3.03$ & $1063.48 \pm 72.32$ \\
Chemical Oxygen Demand (t/yr) & $1267.77 \pm 117.43$ & $193.45 \pm 30.98$ & $52.29 \pm 22.66$ & $3365.94 \pm 474.75$ \\
Total Phosphorus (t/yr) & $34.76 \pm 3.66$ & $7.23 \pm 1.54$ & $7.56 \pm 6.38$ & $157.15 \pm 21.19$ \\
Soluble Reactive Phosphorus (t/yr) & $21.45 \pm 3.21$ & $5.88 \pm 2.02$ & $5.28 \pm 4.79$ & $95.81 \pm 20.60$ \\
Total Nitrogen (t/yr) & $634.79 \pm 75.48$ & $166.13 \pm 52.10$ & $135.14 \pm 113.14$ & $2196.87 \pm 205.08$ \\
Ammonium (t/yr) & $108.91 \pm 24.95$ & $21.16 \pm 9.12$ & $29.14 \pm 33.66$ & $223.03 \pm 32.89$ \\
Nitrate (t/yr) & $266.40 \pm 56.94$ & $60.45 \pm 19.71$ & $34.01 \pm 30.25$ & $766.84 \pm 151.98$ \\
\hline
\end{tabular}

\section{DISCUSSION}

Studies of physico-chemical characteristics of river Lwiro water suggests that the various parameters depend upon the hydrochemistry of the study area, the waste water released by Kakondo industry and runoff water from farm around the microcatchment. The $\mathrm{pH}$ of water is directly related to carbonate and bicarbonate ions present in it, which is closely associated with $\mathrm{CO}_{2}$ pressure and the ionic strength solution (Shraddha et al., 2011). Generally, the obtained $\mathrm{pH}$ values fall within the limit value of WHO (2003) and Uganda standard (Moses, 2005). The river Lwiro micro-catchment has a neutral $\mathrm{pH}$ that varies from site to site between 6.05 and 8.9 as other rivers in Africa (Iwuoha and Osuji, 2012; Loko et al., 2013; Bagalwa et al., 2013a).

It is a well-established that dissolved oxygen budget of a river is a direct indicator of its biological state as was also suggested by Wetzel (2001). The combination of low temperature, high current velocities and low 
disturbance of the site is likely to ensure high dissolved oxygen at the site $1(6.2 \pm 0.46$ $\mathrm{mg} / \mathrm{L})$. A considerable reduction in dissolved oxygen was observed at the agricultural effluent $(4.94 \pm 0.97 \mathrm{mg} / \mathrm{L})$ and industrial effluent $(2.68 \pm 1.64 \mathrm{mg} / \mathrm{L})$. Downstream from site 5, dissolved oxygen seems to stabilize and decrease gradually as far as the outlet $(5.4 \pm 0.55 \mathrm{mg} / \mathrm{L})$. These variations were also observed in other works in the region and elsewhere (Hecky et al., 2003; Bagalwa, 2006; Bagalwa et al., 2013a; Bagalwa et al., 2013b, Loko et al., 2013). All these studies showed that DO decreased downstream but $\mathrm{BOD}_{5}, \mathrm{SS}$ and temperature increased downstream. Dissolved oxygen values in the river water was low as observed also in the Ebrié lagoon of Côte d'Ivoire range between $4.25 \mathrm{mg} / \mathrm{L}$ and $4.57 \mathrm{mg} / \mathrm{L}$ (Loko et al., 2013). TP was high in the industrial site $(1.89 \pm 1.76 \mu \mathrm{mol} / \mathrm{L})$ but a low value was recorded in other sites which were below in the UNECE (1994) and Uganda standards limit (Moses, 2005). Phosphorus, an element necessary for plant growth, is the main cause of eutrophication and of water quality deterioration. Even minimal phosphorus content (some 0.25 of $\mu \mathrm{mol} / \mathrm{L}$ ) can constitute a dangerous pollutant. Thus, according to the ECE (Economic Commission for Europe of the United Nations), (1993) classification of surface water, water is considered fairly eutrophic as of $0.64 \mu \mathrm{mol} / \mathrm{L}$. The industry formally used to treat coffee is also used to treat mineral coming from artisanal extraction in the mountain. This is probably the source of phosphore recorded in the samples but also human excreta and detergents considered as the second natural origin of phosphate (O’Neill et al., 2011; Wang and Pant 2012) is pointed. During the dry season, the concentration of phosphorus is low than in wet season. The input of this nutrient by erosion of excreta and dead material in the catchment occurred in wet season in September, April and May and the concentration of phosphorus increased. Phosphorus is analyzed as soluble phosphate or as full phosphorus. It quickly develops into such low soluble forms as apatite. Much of the phosphorus is adsorbed into particles and suspended matter (Rosli and Yahya, 2012). As a result, soil acts as a phosphorus reservoir restricting the impact of excess supplies. A very strong correlation was observed between TSS and this nutrient. All the physicochemical parameters investigated in this study shows are ranged between the limit of WHO (2003), Uganda standard (Moses, 2005) and UNECE (1994). The results of the present study showed that the correlation between selected physico-chemical parameters and sites are positively correlated $(\mathrm{F}=16.13, \mathrm{p}=$ 0.001).

Results show that the annual $\mathrm{BOD}_{5}$, COD, TSS and nutrient load were the lowest on the industrial effluent in domestic and agricultural effluent and in those recorded at the outlet. Except for $\mathrm{NH}_{4}{ }^{+}$which were higher in industrial effluent than in agricultural one. These findings reveal that diffuse source is the main source of pollutant in Lwiro microcatchment. This shows that the contribution of runoff directly to the river is also contributed to the general load. Erosion occurring in the Lwiro river micro-catchment is the main source as observed by Mason (1981). A weak positive correlation between discharge and TSS load ( $\mathrm{r}=0.36)$ has been noticed. Pearson's correlation will help to understand the nature of the physico-chemical variables and their species speciation in Lwiro river. It is observed that an increase in concentration of pollutants will occur during the beginning of farming. Correlation analysis is very useful in establishing the physico-chemical parameters association within sites in a given study area (Thirupathaiah et al., 2012). This 
analysis was done in an attempt to find out which of the parameter are associated and common to various sampling sites within the study area. It is proved that TSS and COD load are very strongly associated with nutrient. Temporal variation and site difference between TSS $(\mathrm{F}=5.543, \mathrm{p}<0.005)$, $\mathrm{TP}(\mathrm{F}=8,597, \mathrm{p}<0.005)$ and $\mathrm{TN}(\mathrm{F}=7.638$, $\mathrm{p}<0.005)$ load were significantly different.

The maximum of TSS load was recorded in dry season whereas the maximum discharge was noticed in wet season. This observation was attributed to the activities of population in this period of agriculture. TSS load is affected by natural condition (soil erosion, streambed resuspension) and can be affected by human activities (construction, timber harvesting, certain agricultural practices and hydraulic alteration). It is linked to the transport through river systems of nutrients (especially phosphorus), metals and a wide range of industrials and agricultural chemicals (Senus et al., 2004). TSS levels and fluctuation influence aquatic life from phytoplankton to fish, reduce water clarity, light penetration in the water column and is a useful indicator for assessing the effects of land use changes and engineering practices in watercourses (Senus et al., 2004). Nutrients are required to sustain life, but excess nutrient loads can upset the nutrient cycle balance resulting in changes in water quality harmful to organisms (Aldous et al., 2005). Most TN recorded in the sample is possibly from the farmlands and may be in the form of Nitrate washed with the sediment into the river. The high load of nitrate in the agricultural effluent can be attributed to this phenomenon and the high $\mathrm{NH}_{4}{ }^{+}$recorded in the industrial effluent can be attributed to the decomposition of dead peel of coffee discharge in the effluent.

Most of the African rivers that have been monitoring drain either heavily urbanized or heavily cultivated areas. TSS concentration is high in these African rivers than in Lwiro micro-catchment because the rivers drain in Lwiro micro-catchment are drain in rural area and some time pass through wetlands were they reduce at certain concentration of TSS, nutrients and other physico-chemical parameters loads before they reach in the main river (Bagalwa, 2006). But as a result of cultivation on steep hill slopes, the minimal application of soil conservation measures and deforestation should be applied. It appears that the input of organic material to rivers has been accelerated in the Lwiro micro-catchment. This impact may affect the biodiversity and soil fertility as a consequence decline crop yield in the microcatchment. The disturbance of natural vegetation at the shoreline of the rivers in an agricultural region will impact seriously the water quality.

\section{Conclusions}

The study has provided information about the water quality status, sediment and nutrient load in Lwiro river. The result indicated that the concentrations of the investigated physico-chemical parameters in the water samples from Lwiro river microcatchment were found to be acceptable according to the guidelines for surface freshwater quality for the maintenance of aquatic life provided by the UNECE and Uganda standard. The water quality assessment of Lwiro micro-catchment indicates that the non point source (agriculture) is the main source of sediment and nutrient load in the micro-catchment. Sediment and nutrient is high during the beginning of field plantation between July and September. The annual load of TSS, TN, TP are high at the outlet of the river Lwiro compared to others sites. The impact of anthropogenic activities in Lwiro river microcatchment could lead to water deterioration 
and loss in its biodiversity value. The conditions and practices which contribute to the high load of sediment and nutrient and other pollutants entering the Lake Kivu from Lwiro river are especially the inappropriate methods of maintaining soil moisture contents (deforestation), the lack of suitable and integrated agricultural practices and the conversion of wetlands which are sediment trap for agricultural production.

The following recommendations are made:

- Monitoring in other Lake Kivu tributaries should also be done, in order to improve the capacity to predict how the lake will respond to continuing changes in land use.

- Techniques for reducing load of nutrient and sediment due to erosion should be initiated in the catchment to protect the shoreline of rivers in the micro-catchment (vegetation planting).

- Treatment of water coming from the industry before entering the main river.

- Conservation of the wetland along the river channel.

- Education of farmers about the conservation of aquatic ecosystem.

\section{ACKNOWLEDGEMENTS}

This research was funded by RUFORUM under Makerere University, Uganda. We acknowledge the technical help of Bayongwa, Ndegeyi, Enock Wani and Gyslain Irenge for the Centre de Recherche en Sciences Naturelles of Lwiro.

\section{REFERENCES}

Aldous A, McCormick P, Graham S, Craft C. 2005. Hydrologic regime controls soil phosphorous fluxes in restoration and undisturbed wetlands. Restoration Ecology, 13(2): 341 - 347.
APHA (American Public Health Association), 1989. Standard Methods for the Examination of Water and Wastewater. (18 ${ }^{\text {th }}$ edn). APHA: Washington DC, USA, $1587 \mathrm{p}$.

Bagalwa M, Karume K, Bayongwa C, Ndahama N, Ndegeyi K. 2013. Land-use Effects on Cirhanyobowa River Water Quality in D.R. Congo. Greener Journal of Environment Management and Public Safety, 3(1): 21 - 30.

Bagalwa M, Majaliwa JBM, Mushagalusa N, Karume K. 2013. Estimation of Transported Pollutant Load from Small Urban Kahuwa River Micro-catchment in Lake Kivu, Democratic Republic of Congo. Journal of Environmental Science and Engineering B, 2: 460 - 472.

Bagalwa M. 2006. The impact of land use on water quality of the river Lwiro, Democratic Republic of Congo, Central Africa. African Journal of Aquatic Science, 31(1): 137 - 143.

Banadda EN, Kansiime F, Kigobe M, Kizza M, Nhapi I. 2009. Landuse-based non point source pollution: a threat to water quality in Murchison Bay, Uganda. Water Policy, 11(1): 93 - 104.

Buck O, Niyogi DK, Townsend CR. 2004. Scale-dependence of land use effects on water quality of streams in agricultural catchments. Environmental Pollution, 130: 287-299.

D’Oreye N, Gonzalez P J, Shuler A, Oth A, Bagalwa L, Ekstrom G, Kavotha D, Kervyn F, Lucas C, Lukaya F, Osodundu E, Wauthier C, Fernandez J. 2011. Source parameters of the 2008 BukavuCyangugu earthquake estimated from InSAR and teleseismic data. Geophys. J. Int., 184 : $934-948$.

Fan X, Cui B, Zhao H, Zhang Z, Zhang H. 2010. Assessment of river water quality in Pearl River Delta using multivariate 
statistical techniques. Procedia Environmental Sciences, 2: 1220-1234.

Golterman HL, Clymo RS, Ohnstad M. 1978.

Methods for Physical and Chemical Analysis of Fresh Waters. Blackwell: London; 213.

Hecky RE, Bootsma HA, Kingdon ML. 2003. Impact of land use on sediment and nutrient yields in Lake Malawi/Nyassa (Africa). Journal of Great Lakes Research, 29(2): 139-156.

Iwuoha GN, Osuji LC. 2012. Changes in Surface Water Physico-Chemical Parameters following the Dredging of Otamiri and Nworie Rivers, Imo State of Nigeria. Research Journal of Chemical Sciences, 2(3): 7-11.

Li S, Zhang Q. 2008. Geochemistry of the upper Han River basin, China. 1. Spatial distribution of major ion compositions and their controlling factors. Applied Geochemistry, 23: 3535-3544.

Liu S, Zhang J, Chen H, Wu Y, Xiong H, Zhang Z. 2003. Nutrients in the Changjiang and its tributaries. Biogeochemistry, 62(1): 1-18.

Loko S, Ahoussi KE, Koffi YB, Kouassi A. M, Biémi J. 2013. Anthropogenic Activities and the Degradation of the Environmental Quality in Poor Neighborhoods of Abidjan, Côte d'Ivoire: Abia Koumassi Village. Journal of Environmental Protection, 4: 1099-1107.

Mason CE. 1981. Biology of Freshwater Pollution. Longman: London; 100.

Mavonga, T, 2007. Some characteristics of aftershock sequences of major earthquakes from 1994 to 2002 in the Kivu province, Western Rift Valley of Africa. Tectonophysics ; 439: 1- 12.

Moeyerson J, Trefois Ph, Lavreau J, Alimasi D, Badriyo I, Mitima B, Mundala M, Munganga DO, Nahimana L. 2004. A geomorphological assessment of landslide origin at Bukavu, Democratic Republic of the Congo. Engineering geology, 72: $73-87$.

Muvundja FA, Pasche N, Bugenyi WBF, Isumbisho $\mathrm{M}$, Muller $\mathrm{B}$, Namugize JN, Rinta P, Schmid M, Stierli R, Wuest A. 2009. Balancing nutrient inputs to Lake Kivu. Journal of Great Lakes Research, 35: $406-418$.

Onyango RA, Onyango JO, Chemeli MC, Becht R. 2005. Analysis of sediments surface runoff and nutrient dynamics using agricultural non-point source pollution model (AGNPS) in Minera subcatchment of Lake Naivasha drainage basin, Kenya. $11^{\text {th }}$ world lakes conference, Nairobi, Kenya, 31 Octobre to $4^{\text {th }}$ November 2005, $606-614$.

Moses O. 2005. Baseline study of the status of water quality monitoring in Uganda. Nile Basin Water Quality Monitoring Baseline Report for Uganda, 93p.

O’Neill A, Foy RH, Phillips DH. 2011. Phosphorus retention in a construct wetland system used to threat dairly wastewater. Bioresource Technology, 102: 5024 - 5031.

Rosli NRM, Yahya K. 2012. Assessment of nutrient and sediment loading in a Tropical River System in Malaysia. International Conference on Environment Chemistry and Biology, IPCBEE, 49(16): $75-79$.

Schmid M, Busbridge M, Wuest A. 2010. Double-diffusive convection in Lake Kivu. Limnol. Oceanogr., 55: 225-238.

Sensus MP, Langhand MJ, Moyer DL. 2004. Nutrient and Sediment concentration loads and trends for four nontidal tributaries in the Chesapeake Bay watershed, 1997-2001: US Geological 
Survey Scientific Investigation Report, 2004-5125, 27p.

Shraddha S, Rakesh V, Savita D, Praveen J. 2011. Evaluation of Water Quality of Narmada River with reference to Physcochemical Parameters at Hoshangabad city, MP, India. Research Journal of Chemical Sciences, 1(3): 4048.

Thirupathaiah M, Samatha C, Sammaiah C. 2012. Analysis of water quality using physico-chemical parameters in lower manair reservoir of Karimnagar district, Andhra Pradesh. International Journal of Environmental Sciences, 3(1): 172 - 180.

UNECE. 1994. Standard Statistical Classification of Surface Freshwater Quality for the Maintenance of Aquatic Life. In Readings in International Environment Statistics. United Nations Economic Commission for Europe: United Nations, New York and Geneva.
Verhaeghe M. 1964. Inventaire des gisements calcaires, dolomies et travestins du Kivu, du Rwanda et du Burundi. Departement Geologie et Mines du Burundi, 95pp.

Wang J, Pant HK. 2012. Estimation of phosphorus bioavailability in the water column of the Bronx River, New York. Journal of Environmental Protection, 3: $316-323$.

Wang XL, Lu YL, Han JY, He GZ, Wang TY. 2007. Identification of anthropogenic influences on water quality of rivers in Taihu watershed. J. Environ Sci-China, 19: 475-481.

Wetzel RG. 2001. Limnology: Lake and Rivers Ecosystems ( ${ }^{\text {rd }}$ edn). Academic Press; 1006.

WHO. 2003. Guidelines for Drinking Water Quality. WHO: Geneva. 